\title{
EXPERIENTIAL LEARNING IN African PlanNING SCHOOLS: \\ REFLECTIONS ON THE Association of African \\ Planning Schools (AAPS) case study project
}

\author{
NANCY OdendaAL
}

\begin{abstract}
R E S U M O Em 2009 a AAPS entrou em um projeto intitulado "Revitalizando o Ensino de Planejamento" financiado pela Fundação Rockfeller. Este projeto encontra-se atualmente em sua segunda fase. Seu objetivo primário é distanciar o planejamento de suas origens focadas no controle (ainda em prática em muitas partes do continente africano) e reinventá-lo como uma prática que apoie os pobre nas cidades africanas. Um ponto de inicio para fazer isto de forma prática foi formulada sob a forma de um segundo projeto focado na pesquisa de estudos de caso e de documentaçáo. Usando a ideia de phronesis desenvolvida por Bent Flyvbjerg como ponto de partida, a AAPS viabilizou uma série de oficinas e publicaçóes sobre o método, como uma ferramenta de ensino e produção de conhecimento. Este artigo reflete sobre a dimensâo pedagógica em particular, tratando dos resultados e implicaçóes do projeto para o ensino na pós-graduação, ao mesmo tempo em que trata de estúdios de projetos colaborativos implementados junto com a ONG Internacional de Moradores de Favela (Slum Dwellers International) para refletir sobre as modalidades possiveis para alcançar uma melhor aprendizagem experimental.
\end{abstract}

Palavras-Chave África, Planejamento, Ensino, Estudos de Caso, Favelas.

\section{INTRODUCTION}

...[I]t is only the story that can continue beyond the war and the warrior. It is the story that outlives the sound of war-drums and the exploits of brave fighters. It is the story... that saves our progeny from blundering like blind beggars into the spikes of the cactus fence. The story is our escort; without it, we are blind. Does the blind man own his escort? No, neither do we the story; rather it is the story that owns us and directs us.

Chinua Achebe, Anthills of the Savannah (1987)

The tradition of story telling is not unique to the African continent, but its poignancy is illustrated by its ubiquitous presence in tradition. Learning from the products and processes of storytelling is richly embedded in the many cultures that span this vast continent. The experiential connection that enables a good tale to be internalized and influence ways of seeing and knowing is not limited to literature, film or music. It offers the means to gaining insights into the layered complexities that make up African urban spaces.

This paper tells its own story. In 2008, the Association of African Planning Schools (AAPS), a network of 44 universities from 15 countries across (mostly Anglophone) Africa that teach urban and regional planning degrees, embarked on an ambitious undertaking aimed at revitalizing planning education in Africa. This 
project, funded by the Rockefeller Foundation, had a number of objectives. The first relates to curricula reform. The intention was to develop teaching content and methodologies that respond to current African urban issues and engage with the many dimensions of cities on the continent. This requires a shift in current approaches and has implications for the training of planners, the legislative environment within which planners practice as well as the research capacity of planning educators. This process has been recorded in two publications (See Odendaal, 2012; Watson and Odendaal, 2012) with an emphasis on the process of network building and the resource constraints faced by planning schools in Africa.

At the inaugural workshop of the AAPS in Cape Town, South Africa, in October 2008 substantial discussion focused on the value of using case study research documenting and teaching on planning in Africa. Subsequently, in 2009, the AAPS commenced a second project, one with the pertinent aim of advancing the case study method in teaching and research. This is the focus of this paper.

The point of departure of this project is that the case format allows for deeper interrogation of context and a more nuanced understanding of African urban spaces and planning practices. One of the key principles that informed it was that future curricula reform should allow for deep circumstantial engagement. The practical and concrete knowledge gained from the interrogation of cases (potentially) contributes to the representative body of research and publication on African cities. Furthermore, the experiential learning that could be gained from the interrogation of a welldocumented case is a powerful teaching aid. The narrative contained in case study documentation sometimes challenges assumptions and preconceived notions of events and trends (Flyvbjerg, 2001). Telling the story behind the statistics and gaining insights into the manifestation of global trends at a local scale are worthy inputs into the ongoing enquiry into African urbanization.

Case study research could, on the surface, reveal a story about the inadequacies of planning policy; on a deeper level, it potentially uncovers the rationalities that inform practice. As a means to knowledge production, documenting in-depth cases enables insight into less overt factors that impact on practice: values, power relations and decision making processes.

Flyvbjerg (2001) places power at the center of social enquiry, while Simmons (2012) elaborates on this in arguing for training practitioners that work towards social justice through ingraining practical knowledge. The importance of differing access to power, the dance between political power and change, that intricate interplay between knowledge and power, are qualities not unique to the African context. What distinguishes planning in many of the Continent's cities however, is the extent to which planning contributes to the abuse of power and increasing marginalization. Uncovering these stories, as done by Nnkya (2008) in urban Tanzania, by Lerise (2005), regarding land in the same country, and by Watson (2002) in documenting Cape Town post-Apartheid planning process, provides the research community with data that looks beyond the what of planning but interrogates more close the why and how.

The methodological challenge is to identify cases that allow for rich enquiry, that are contextually relevant and will contribute to African scholarship. This requires skills that enable researchers to identify and source appropriate cases and discern significant features whilst understanding the contextual significance of them (in terms of broader practice, legislative reform etc.). Situating cases within international literature and 
debates is important. Applying this learning in teaching and research offers rich opportunities for learning. To this end, the AAPS organized three regional workshops (Accra, Johannesburg and Dar es Salaam) on the case study method, working with representatives from member schools in doing so. These events focused on two aspects: research methodology and teaching. Colleagues were asked to share current work using the case method, which was then discussed, and also share their teaching experiences. Some of these cases have been developed into papers and will form part of a book currently being compiled by AAPS secretariat staff.

The overwhelming emphasis of this initiative has been on research. Somehow the teaching dimension faded into the background as AAPS members debated the pros and cons of case methodology. Yet a question remained; could planning utilize the case study method in teaching much as the way that lawyers and business schools do using the Harvard and other methods? What defines a distinctive case study approach for planning educators in African particularly? In the second round of the Rockefeller funded Revitalizing Planning Education program, a collaborative project with Slum Dwellers International ${ }^{1}$ (SDI) partially answered that question. The studio method may give insight into what defines a uniquely planning pedagogy. Thus, by being part of the story, students stand to gain from their immersion into the everyday.

This paper uses the two AAPS experiences - collaborative studios with SDI affiliates and the case study workshops - to explore the value of experiential learning in planning. The bigger story is of the effort to create a new cadre of professionals that are equipped with the sensitivities, sensibilities and skills to make meaningful contributions to practice. This paper argues for the case study method as one of the primary means of achieving that and reflects on the AAPS experience in doing so.

\section{THE AAPS EXPERIMENT}

'Ideas are not fixed and immutable elements of thought but are formed and re- formed through experience.' (Kolb, 1984, p. 26)

Experiential learning is defined by Kolb (1984) as 'the process whereby knowledge is created through the transformation of experience. Knowledge results from the combination of grasping and transformation experience'. Experiencing, reflecting on that experience and then conceptualizing to the point where such knowledge is applied through active experimentation, is typically seen as the experiential learning process. As a pedagogical mode it engages active learning; students 'do' while internalizing the implications of theory in applying it to practice. The aim of to achieve familiarity with the realities that planners would have to deal with in the 'everyday'.

The three regional workshops that yielded this text explored the intricacies, as well as the implications of the case study method, for African planning academics. Flyvbjerg (2001) mentions in Making Social Science Matter the methodological prejudice that many of his African colleagues face in their universities. This was certainly echoed at the AAPS workshops: the case study method is still regarded as a poor (qualitative) substitute for 'rigorous' quantitative research. Funding, higher degree approvals and promotional prospects follow suit. The academic environment in African planning education is not necessarily conducive to phronetic knowledge
1 The AAPS and SDI have agreed to collaboration under a Memorandum of Understanding between the two organisations that allows for joint curricular work and research. 
generation (and may well provide material for developing cases that explore the power dynamics of the African educational environment).

In the AAPS 'Revitalizing Planning Education' project; it soon became apparent that what is key to planning educational reform is a shift in values towards a frame more attuned with inclusive cities. The potential for shifting mindsets of students became apparent at the 2010 biennial AAPS workshop in Dar es Salaam when during a Kenyan affiliate of SDI, a former student poignantly reflected on how this exposure changed the way he thinks about informality, and consequently, the city. This 'learning from below' is reflective of a teaching approach that immerses planning students in informal settlements, whilst honing their skills as researchers of a 'live' case, exposing them to the strategies and practical knowledge that inform livelihoods at the margins. The studio, situated in an informal settlement, enabled this learning.

In his review of the use of the case study method at Harvard University, Garvin (2003) uses the subtitle "Professional education for the world of practice" in explaining the origins and current approaches used in the institution's business, law and medical schools. Each of these professions has its own bias in terms of material presented, the form of interrogation and the means through which students are expected to engage. The Harvard method is one influential case teaching approach (Barnes et al 1987). It is a resource intensive approach, meaning that teachers must research cases, write them up and prepare class materials before the teaching session. It therefore requires having extensive access to relevant case data. The case is presented as 'open-ended' so that students prepare by discussing solutions and outcomes within learning groups. In the classroom, the lecturer fulfills a role as a facilitator, by encouraging interactive discussion and calling upon students to provide solutions.

The pedagogical slant is clearly informed by the professional boundaries within which the graduate is expected to engage. The question is then: what distinguishes planning and how best can one enable experiential learning that best serves its professional demands? Whilst the Harvard method is recognised globally as being an effective teaching approach, the fact remains that it depends upon simulation - the classroom situation is used to simulate real business cases. This lack of contact with the real world limits its learning potential, especially for disciplines, such as planning, which are based on the analysis and production of the physical built environment. Using the case study method in planning opens up opportunities for new and innovative application in that students are immersed into the physicality of place as well as the production of space. They intervene in real time, outside the domains of the classroom. In this way, the case method is useful for teaching the complexities of African urban areas. By doing fieldwork and experiencing urban spaces hands-on, students develop a nuanced understanding of how complex African cities work.

Harvard Law School first started using case histories in 1870, the Business School in 1908 and the Medical School in 1985 (Garvin 2003, p. 56). The Kennedy School of Governance at the same institution uses process cases to track public decision making in its instruction (http://www.case.hks.harvard.edu). What became apparent at the AAPS case study workshops is that planning schools use cases in many ways either implicitly or explicitly with the one distinguishing feature being onsite engagement. The primacy of the studio method was apparent.

The following sections review two AAPS experiences in this regard: it draws on work produced for the three regional workshops and the ongoing collaborative studios with SDI. 


\section{AAPS MEMBER EXPERIENCES IN CASE STUDY TEACHING}

The teaching cases presented at the regional workshops shared one common feature: students were expected to engage in rigorous fieldwork. This section reflects on three of the workshop inputs in particular. In Johannesburg, Sarah Charlton's students interviewed informal waste collectors (scavengers) in the city, with the aim of understanding their movement patterns and housing needs. In Kampala, Uganda, Stephen Mukiibi and his students form Makerere University worked in an informal settlement as part of their planning studio. They were expected to provide continuous feedback to residents and City Council officials. Karina Landman's students at the University of Pretoria in South Africa used the live case of Cosmo City in Johannesburg, a privately developed integrated low-to medium income settlement, to interrogate integrated development.

The focus on these three experiences and discussion with other AAPS members revealed that there are varying modalities used in the field and in the university for incorporating cases into planning teaching. The diagram below develops a spectrum of such in relation to delivery methods.

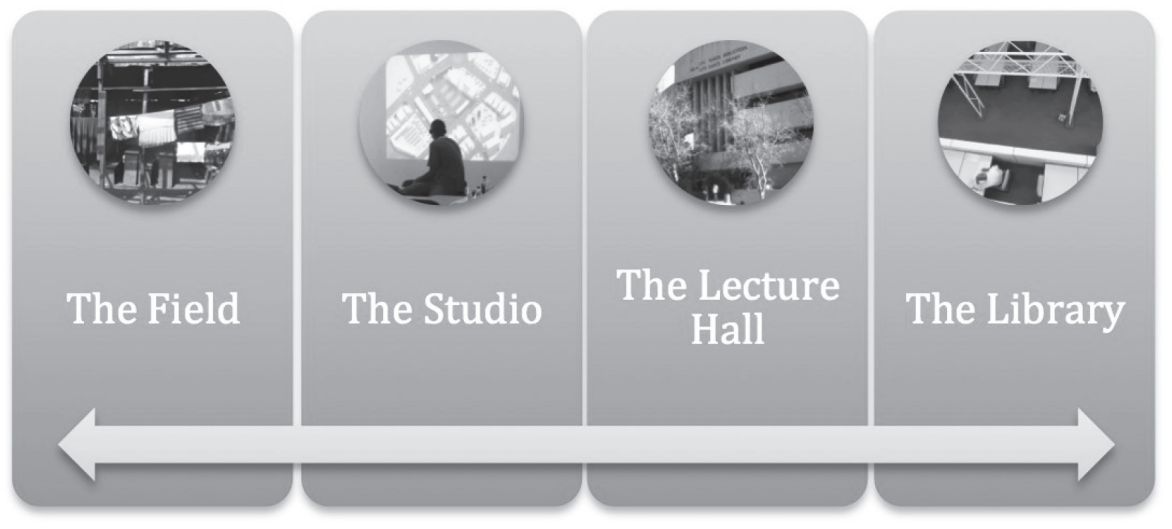

The left hand of the spectrum represents the closest the student can get to reality, the actual field...informal settlements, redevelopment areas, natural conservation areas, the city...

The right hand is the most removed from the field, the library. What is evident is the three cases presented in this text, is that the use of cases in planning teaching moves the students between these four locations, sometimes very fluidly and to the benefit of the learning experience. One case could involve a range of delivery methods. Similarly one case can be used for different learning outcomes in the different teaching settings. Not only does this enhance the student's ability to integrated various sources of learning into one experience but its also presents multifaceted exposure to the case.

Using this frame, a number of questions with regards to using the case study method in teaching emerged: how does one prepare the case, what is the role of the instructor and others, and what are the outcomes (and implications) of such processes? 


\section{Case Preparation}

The various schools within Harvard University share an institutional infrastructure for the preparation of cases for teaching. This includes online resources, teacher notes, open- ended case write-ups that enable engagement and teaching spaces that allow for multimedia engagement. Clearly not all African planning schools are as well resourced and it is therefore no coincidence that two of the three examples quoted here were prepared in relatively well-established South African universities. Yin (2009) argues that a teaching case is sometimes left open-ended to allow for student engagement in the conclusion of events, and needn't "...contain a complete or accurate rendition of actual events" (Yin 2009, p. 357). Online examples of those prepared by South African based think tank Urban Landmark on how urban land markets work in Africa, for example, present the instructor with notes and lead questions for students $(<\mathrm{http}: / /$ www.urbanlandmark.org.za/research/x18.php>). The open-endedness of learning cases enable role-play, preparation of solutions to onsite problems and maximizes opportunities for creativity.

Taking students into the field and employing their skills to solve a common research problem was the approach taken by Charlton in studying informal recyclers in Johannesburg. Students made input into the research design, as well as discussions with the City of Johannesburg on how the outcomes of this exercise could be of broader benefit. The role of Charlton was that of facilitator, enabling exchange between students and the City, ensuing ethical clearance from the University of the Witwatersrand, leading students in their research and enabling the collation of findings as well as input thereof into the course syllabus. In presenting the case Charlton concluded that substantial time is necessary to process findings of such a collective case research effort. This needs to be incorporated into the design. And of course, such a research exercise includes a literature review and engagement with conceptual material - some of which to be done by student but mainly the responsibility of the instructor (the library).

The choice of case clearly comes with its own demands in preparation. In another South African case, Landman argues that the choice of case is directly related to teaching outcomes. In considering her use of the Cosmo City housing development outside Johannesburg, she outlines five considerations in this regard: the type of case, the unit of analysis that best serves teaching interests, the data available, research methods and their practical application by students and of course, the teaching strategies that best accommodate such learning. In her example, the research had been prepared by a well-resourced and established semi-public research agency, at which she was previously employed.

The case study unit in relation to learning outcomes is an important starting point. In Charlton's case her focus was on individual livelihood strategies and how they reflect larger issues of housing and income. Students were therefore required to do individual interviews, and associated participant observation. Landman's students were required to engage with the nature and appropriateness of medium density mixed housing in South Africa. The project is the unit: its management, history, financing and physical layout.

In Stephen Mukiibi's studio project, students are challenged to immerse themselves

in a live case. The Bwaise informal settlement in Kampala as a unit presented the 
students with a chance to engage the notion of informal settlements, but also relate to the sub- units, the structures and infrastructural elements that make up the space. As future architects and planners they were then expected to intervene in these subunits, enhancing their learning of the whole. What then is required of the instructor in enabling case learning through studio? If not planned carefully, and managed with learning outcomes in mind, students can get distracted in the field and waste project time, Mukiibi argues. Substantial preparation is required in meeting members of the community and the municipality. In his Ugandan case, tutors were employed to ensure that the academic timeline was adhered to. Thus the role of the instructor is critical to determine beforehand because it often goes beyond that of lecturer.

\section{The Role(s) OF THe Lecturer/ Instructor ANd Others}

Two of the examples, Charlton and Mukiibi, enabled a feedback loop to central actors in the cases. Johannesburg and Kampala city councils were involved in project outcomes, which require ongoing exchange between faculty and officials. Landman was able to involve researchers outside the confines of her university. Clearly as students are challenged to engage experience, it lets the 'outside world' in.

The academic staff member's role ranges from facilitator, project manager to researcher and intermediary. As the direct engagement with the cases lessens to more of a simulation or desktop research exercise, the role becomes more traditional. The student's role varies from proxy professional to researcher to learner. Of course, using role-play, the student's role can temporarily be suspended to take on roles in a teaching case, thereby 'playing' at an outcome and gaining insight into the implications of certain actions. Outside actors such as intermediaries such as community leaders in Mukiibi's case, outside researchers in Landman's and the actual research subjects, the recyclers, in Charlton's case also come into the fray. As the learning experience moves further away from the field towards the library, the extent to which the faculty member has control over the circumstances of the case increases, but opportunities for experiential learning decrease.
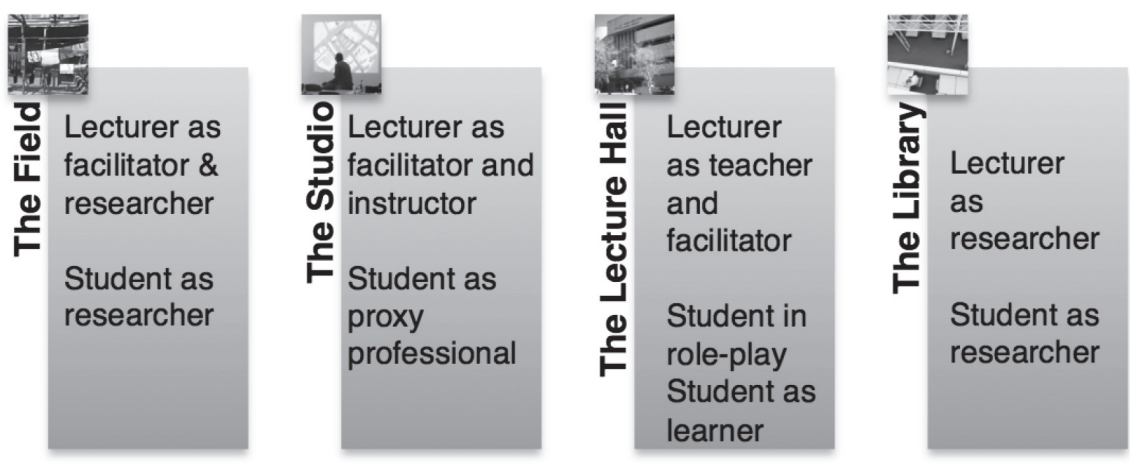

Immersing students in the field with other role players not has implications for preparation and facilitation but also impacts on others outside the university system. The following section describes the collaborative studio initiative with SDI. 


\section{COLLABORATIVE PLANNING STUDIOS WITH SDI}

The AAPS meeting in Dar es Salaam in 2010 showcased the existing collaboration between the University of Nairobi and SDI affiliates referred to earlier, and also planted a seed. The second round of Rockefeller funding facilitated three collaborative planning studios; two in Malawi and another in Uganda. Three more are planned in Zimbabwe, Tanzania and Namibia. Funding enables SDI staff to help organize and run the workshops and field costs associated with the actual studio. The studios run for a month on average. The choice of planning schools was influenced by SDI presence. If the SDI affiliate is active in a location at which there is an AAPS planning school, this school was approached with the opportunity of doing a collaborative studio. Clearly learning outcomes have to coincide with SDI affiliate aims, and sometimes this had to be negotiated carefully beforehand. Also, the studio had to fit with the school's planning curriculum.

In February 2013, an opportunity for reflection emerged as AAPS hosted a workshop on collaborative studios following the SDI 5-Cities Seminar in Cape Town. (<http://www.sdinet.org/blog/2013/02/12/taking-academia-slums-aaps-attends-5cities- seminar>). At this meeting, work done by the University of Cape Town (UCT) on collaborative studios with Slum/Shack dwellers International (SDI), presented by Tanja Winkler (2013), and AAPS-SDI collaborative studios in Malawi and Uganda were used as a basis for discussion. AAPS members, SDI representatives and UCT students contributed to the dialogue.

This event resulted in a number of issues being raised with regards to the preparation, operation and implications of collaborative studios. Winkler's input contributed to the identification of three conceptual aims of the collaborative studio approach. In addition to the aim of experiential learning, there were essentially two other related outcomes that underpin AAPS efforts towards collaborative studios: engaged scholarship and knowledge co-production. Salient practical, theoretical and ethical issues raised by participants were then mapped in accordance with these three aims. From this emerged a number of clusters of issues that are discussed here. SDI is defined here as an intermediary, recognizing that collaboration with other community based organisations is possible. (The diagram mapping the individual issues raised in relation to the three aims of experiential learning, engaged scholarship and knowledge co-production is included as Annexure A.)

\section{Practical Preparation: Constraints and Issues}

The choice of site and community was discussed. Part of the issue is how to align intermediary objectives and the learning outcome of planning schools. Some participants wondered if this could be applied in an affluent area? Could students gain from such exposure and would the choice of a between capacitated area present a different set of challenges?

Some discussion centered on project outputs, and whether these could be of use beyond the lifeline of the student project. This raised issues around ongoing collaboration as well as the use of student outcomes in a policy and planning environment.

The importance of the brief was emphasized. Students that participated in the discussion were particularly vocal on how central to project brief was in their experience. This is the thread that holds the project together when it strays from the planned process. 
The question was then raised: how malleable should the student brief be given that the project process may have to shift to accommodate community dynamics?

Some discussion centered on the need to allow for variation in scale as well as level of education - undergraduate versus postgraduate curricula - and the differences that may require in preparing students and choosing a site.

Time and budget were raised as key concerns. Whilst the AAPS funding enabled transport to project sites and other practicalities, some schools expressed concern about doing this in future without this support.

\section{Building Trust and Reciprocal Respect}

The qualitative nature of the relationship between host school and community intermediary was raised as a key concern. These relationships take time to build and may require a long period of preparation before the actual studio. An essential part of this is agreeing on roles and responsibilities of all actors involved.

Participants were adamant about managing community and participant expectations. Ethical issues surrounding managing these expectations and transparency regarding process outcomes would therefore have to be negotiated and stated upfront.

Participants acknowledged that institutional shifts might impact on such projects. A shift in the policy stance of the intermediary organization, a political change in the host community of some inside pressures from the university could destabilize proceedings. Some participants feared that it some of these could compromise learning outcomes. Such shifts could also compromise commitment from some or one of the actors.

\section{Defining the Agenda}

Who defines the agenda and how it is defined is closely related to what it is a planning studio can achieve. From the planning educator's point of view, retaining the credibility o the planning education project is paramount. One participant recommended mapping the agendas of all actors beforehand to enable clarity.

Should the student project result in research that feeds into a larger advocacy agenda, this would need to be negotiated, or the possibility of it would need to be determined beforehand.

The role of the student brief became paramount again. Definition the role and outcomes of the planning studio is a tool for managing expectations

\section{Optimising the Generative Capacity of the Studio}

How do we ensure that the studio process and products have ongoing benefits? This was the big question raised by many. Some questioned the extent to which the studio could benefit all involved parties. The students were particularly concerned about this. Some possibilities were discussion. Organizing 'vertical studios' or interdisciplinary studios that enabled cross learning between difference levels and types of students was discussed as a pedagogical option. The potential of short and Continuing Professional Development (CPD) courses was raised. An exciting possibility is designing studio modalities that eventually incorporate ongoing 'on-site' student presence through voluntary work and/or internships. 


\section{CONCLUSION: CONTEMPORARY TRENDS AND FUTURE POSSIBILITIES}

In the AAPS experience, case study teaching leans towards more collaborative models in the studio. Joint knowledge creation initiatives that enable a reciprocal learning process between communities and students (and staff) speak to learning that goes beyond the traditional Harvard case study teaching approach. This perhaps then, is the distinguishing feature of the case study method and planning. Extending this to include other actors such as community intermediaries presents such pedagogical process with a host of opportunities and challenges.

Perhaps the most profound opportunity is immersing students into the 'everyday' of the African city. Not only are students enabled to engage with physical and broader spatial aspects, but also with the institutional intricacies of such processes. The challenges speak to the resources necessary to enable this, and the substantial preparation required to align agendas of all concerned. There are profound ethical issues, since none of these initiatives are constructed in value-free environments. There is an opportunity here also; the chance to shift mindsets about how the urban poor survive in African urban spaces.

Case study teaching does enable activity, experiential learning and practical skills. The relationship to defined teaching outcomes is absolutely central. The two AAPS projects speak to a broader benefit that stretches beyond conventional teaching objectives. Landman, in documenting the case in the first AAPS case study project argues that the choice of an appropriate case enables the learning of creative, reflective, practical and conceptual skills. She adds the achievement of 'functional integration', enabling new learning that can be applied in different contexts. Thus there is a pedagogical dimension to case study teaching that results in transferable skills and reflective learning.

The studio project with SDI starts showing some of the complexities of reflective learning in a 'live' project. Involving an intermediary is essential in enabling access to certain contexts and also learning from the practical exposure contained therein.

There is also a continuity of learning that can be enabled through proper facilitation. Mukiibi argues that feeding results of projects into other assignments is necessary for ongoing sustainability of participatory studio based projects. There are practical outcome therefore that relate to sharing between courses as well as sharing with other role players. Results of Mukiibi's studio and Charlton's research project were relayed back to the city councils. The case study method potentially enables a closer relationship between practice and theory; perhaps the strongest argument that can be made for a 'planning approach' to the case study method.

In reflecting on both initiatives, the collaborative studios and hearing AAPS

Nancy Odendaal é urban planner; pesquisadora sênior na School of Architecture, Planning and Geomatics African Centre for Cities - University of Cape Town; project coordinator of the Association of African Planning Schools (AAPS), África do Sul. E-mail: nancy.odendaal@uct.ac.za. experiences at the case study workshops, it is apparent that the shift in sensibilities that results from engagement in the field in building a case is potentially profound. The experiential connection that emanates from a deep engagement with context goes beyond descriptive learning. That empathy and understanding of values enables a deep engagement with livelihood strategies, the basis for meaningful, contextually rich practice. As Dewey (quoted in Barnes et al 1987) argued as long back as 1915: 
Thinking which is not connected with increase of efficiency in action, and with learning more about ourselves and the world in which we live, has something the matter with it just as thought... And skill obtained apart from thinking is not connected with any sense of the purposes for which it is to be used.

\section{REFERENCES}

BARNES, L.B., CHRISTENSEN, C.R., HANSEN, A.J. Teaching and the Case Method: Text, Cases and readings (Third Edition) Boston: Harvard Business School Press, 1987.

FLYVBJERG, B. Making Social Science Matter: Why Social Inquiry fails and how it can succeed again. Cambridge: Cambridge University Press, 2001.

. Five Misunderstandings About Case-Study Research. Qualitative Inquiry, v. 12,

n. 2. p. 219-245, 2006.

GARVIN, D.A. Making the Case: Professional Education for the World of Practice, in Harvard Magazine, Volume 106, Number 1, September - October, 2003.

KOLB, D. Experiential learning. Prentice-Hall, Englewood Cliffs, NJ, 1984.

LERISE, F. Politics in Land and Water Use Management: Study in Kilimanjaro, Tanzania. Dar es Salaam: Mkuki na Nyota Publishers, 2005.

NNKYA, T. Why Planning does not work: Land-use Planning and Residents Rights in Tanzania. Dar es Salaam: Mkuki na Nyota Publishers, 2008.

ODENDAAL, N. Reality check: Planning education in the African urban century. Cities 29

(3) 174-182, 2012.

SIMMONS, W.P. Making the Teaching of Social Justice Matter, in FLYVBJERG, B., LANDMAN, T., AND S. SCHRAM (ed.) Real Social Science: Applied Phronesis. Cambridge: Cambridge University Press, 2012. p. 246-263

WATSON, V. Change and continuity in spatial planning: metropolitan planning in Cape Town, Routledge, London, 2002.

.; ODENDAAL, N. Changing planning education in Africa: the role of the Association of African Planning Schools, Journal of Planning Education and Research. 2012. (Online August 15th 2012) DOI: 10.1177/0739456X12452308

WINKLER, T. At the Coalface: Community-University Engagements and Planning Education, in Journal of Planning Education and Research, 33 (2), June 2013.

YIN, Robert, K. Case Study Research: Design and Methods (Fourth Edi.). Thousand Oaks: Sage, 2009.

\section{WEB SITES}

<http://www.case.hks.harvard.edu> (Accessed Feb 2013)

<http://www.urbanlandmark.org.za/research/x18.php> (Accessed Feb 2013)

A B S T R A C T In 2009 the AAPS embarked on a project entitled 'Revitalising Planning Education', funded by the Rockefeller Foundation. This project is currently in its second phase. Its primary aim is to move planning away from its control-focused origins (still 
practiced in many parts of the Continent) and reinvent it as a practice that is supportive of the poor in African cities. An entry point for doing this practically was formulated in the form of a second project that focused on case study research and documentation. Using the idea of phronesis developed by Bent Flyvbjerg as a point of departure, the Association facilitated a series of workshops and publications on the method, as a tool for teaching and knowledge production. This paper reflects on the pedagogical dimension in particular, in reflecting on the project's outcomes and its implications for graduate education, whilst also drawing on recent collaborative studio projects run in conjunction with Slum Dwellers International in reflecting on possible modalities for best achieving experiential learning.

K E Y W O R D S Africa, Planning, Education, Case Studies, Slums 